\title{
COVID-19 and Nutrition ${ }^{1}$
}

\section{Farah Tadros, Susannah Folsom, and Jeanette Andrade ${ }^{2}$}

\section{Background}

According to the Centers for Disease Control and Prevention (CDC), COVID-19 symptoms range from mild to severe and include fever, chills, cough, shortness of breath, fatigue, diarrhea, nausea, congestion, runny nose, and other symptoms (CDC 2021). These symptoms can result in increased energy needs and excessive loss of fluids, which may lead to weight loss and dehydration, respectively (Brugliera et al. 2020; Chan et al. 2018; Fernández-Quintela et al. 2020). Many individuals affected by COVID-19 recover at home, while an estimated $14 \%$ require hospitalization (Stokes et al. 2020). While battling and recovering from this virus, it is important to consume nutritious foods and remain hydrated. The purpose of this publication is to discuss remaining hydrated, foods to consume, and programs and resources that are available as one battles and recovers from COVID.

\section{Importance of Hydration}

Remaining hydrated during and while recovering from COVID-19 is necessary due to symptoms associated with this virus, such as fever, diarrhea and vomiting, that will lead to water loss within the body (Fernández-Quintela et al. 2020; Stachowska et al. 2020). Electrolyte loss, especially potassium and sodium, may impact heart and kidney function (Lacey et al. 2019). It is important for an individual to stay hydrated to help the body fight the virus, support the immune system, and help relieve symptoms experienced (e.g., fever, coughing, difficulty breathing). Below are some recommendations and tips to stay hydrated.

\section{Recommendations and Tips to Stay Hydrated}

Drink about 3 liters of fluid daily ( $\sim 13$ cups) (Institute of Medicine 2005).

- Optimal liquids include:

- Oral rehydration solutions that contain essential electrolytes and minerals

- Fruit juices

- Vegetable, chicken, and beef broth

- Sports drinks

- To avoid taste fatigue, use a variety of liquids.

- Try adding a wedge of lime or lemon to water.

- Keep a beverage near the bed to sip on throughout the night.

For a rehydration liquid recipe, visit the American Society for Enteral and Parenteral Nutrition (ASPEN) at https://www.nutritioncare.org/Guidelines_and_Clinical_Resources/Resources_for_Clinicians_Caring_for_Patients_with_Coronavirus/.

\section{Calories Count}

As the body battles this virus, we need to maintain food intake and consume foods that are high in healthy fats,

1. This publication is FSHN22-1, one of a series of the Food Science and Human Nutrition Department, UF/IFAS Extension. Original publication date February 2022. Visit the EDIS website at https://edis.ifas.ufl.edu/ for the currently supported version of this publication.

2. Farah Tadros, graduate student; Susannah Folsom, graduate student; and Jeanette Andrade, assistant professor and director, MS-DI program, Food Science and Human Nutrition Department; UF/IFAS Extension, Gainesville, FL 32611.

The Institute of Food and Agricultural Sciences (IFAS) is an Equal Opportunity Institution authorized to provide research, educational information and other services

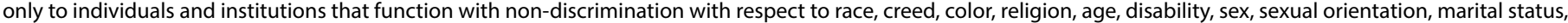

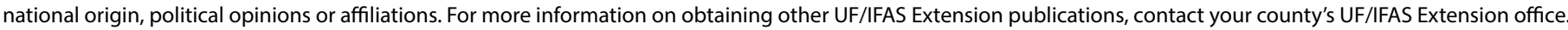
U.S. Department of Agriculture, UF/IFAS Extension Service, University of Florida, IFAS, Florida A \& M University Cooperative Extension Program, and Boards of County Commissioners Cooperating. Andra Johnson, dean for UF/IFAS Extension. 
protein, vitamins and minerals (Brugliera et al. 2020; Fernández-Quintela et al. 2020; Stachowska et al. 2020). Individuals who do not consume enough of these nutrients may prolong their recovery time due to prolonged inflammation and oxidative stress (Iddir et al. 2020). Additionally, if an individual does not consume sufficient food and nutrition or is limited in their mobility (especially if previously hospitalized), unintended fat and muscle loss may occur (Fernández-Quintela et al. 2020; Stachowska et al. 2020). Therefore, it is important than one recovering from COVID-19 consume 25-30 calories per kilogram (1 $\mathrm{kg}=2.2$ pounds) body weight each day (Stachowska et al. 2020). That is up to about 2000 calories for a 150-pound adult. Consuming adequate calories may be difficult due to decreased appetite, diarrhea, nausea/vomiting, and loss of taste or smell. Below are some helpful ways to increase food intake.

\section{Tips for Increasing Calories}

- Aim to eat around 6 times a day (or every 2-3 hours).

- Eat small amounts frequently if larger amounts during mealtimes are challenging.

- Choose nutrient-dense foods (including whole grains, fruits, and vegetables) at each meal and snack.

- Increase the amounts of fats and oils added to foods, focusing on the heathy ones (olive oil, avocado, etc).

- Add some non-salt seasonings (e.g., basil, mint, etc) to dishes if taste is affected.

- Use high-calorie liquid nutrition supplement when unable to meet calorie needs through food and beverages (Brugliera et al. 2020; Fernández-Quintela et al. 2020; Iddir et al. 2020). Consult with a doctor or a registered dietitian nutritionist for further information about these supplements.

\section{Pack in the Protein}

During COVID-19, protein is important because it helps rebuild muscle tissue and maintain muscle mass (Cohen, Nathan, and Goldberg 2014). Research shows that adequate protein can help with antibody production, which is important when fighting COVID-19 (Balachandar et al. 2020). It is recommended that an individual consume between 1-1.2 grams of protein/kilogram body weight daily (Stachowska et al. 2020). Aim to eat at least one serving of protein at each meal and as a snack to meet these recommendations. In Table 1 are types and amounts of protein within foods.

For those having trouble eating foods that contain protein, making a high-protein shake or smoothie can make it easier to meet the set goal. For an example high-protein shake recipe, visit ASPEN at https://www.nutritioncare.org/ Guidelines_and_Clinical_Resources/Resources_for_Clinicians_Caring_for_Patients_with_Coronavirus/.

\section{Access to Food}

Access to food during this pandemic has become more difficult with job loss and concern of exposure when going to the grocery store (CFS 2020). Those who are exposed, battling, or recovering from COVID-19 are required to quarantine and therefore need to find alternative ways to purchase food. The CDC and local public health departments provide guidelines and recommendations to reduce the risk of exposure. One recommendation for those who have the virus or are recovering is to avoid shopping in person-instead, order groceries online for home delivery, or use curbside pickup and have a family member drop off the groceries from a safe distance (CDC 2020).

\section{Food Assistance Programs}

Following these guidelines, food assistance programs, such as SNAP and WIC, have made adjustments and waived various requirements to help individuals gain access to food and resources remotely.

- Supplemental Nutrition Assistance Program (SNAP)

- SNAP has started an online purchasing pilot in 40 different states, where SNAP participants are able to order their groceries online using government assistance benefits (USDA 2020).

- The requirements for in-person interviews during the SNAP enrollment process and recertification have been waived (USDA 2020).

- Special Supplemental Nutrition Program for Women, Infants, and Children (WIC)

- WIC provides remote access to all services and benefits, including food and nutrition support.

- Various states have also created WIC Mobile Apps where participants can stay up to date with appointments, view food benefits, and be aware of WIC stores and clinics near them.

- WIC has addressed supply challenges and is allowing substitutions when WIC foods are unavailable (USDA 2021).

A focus on consuming enough calories from foods high in healthy fats, proteins, vitamins, and minerals is important when experiencing COVID-19. A healthful diet along with adequate hydration will help support the immune system, 
relieve symptoms experienced, and maintain muscle. Keep in mind the food programs and resources that are also available to help during recovery.

\section{References}

Balachandar, V., I. Mahalaxmi, M. Subramaniam, J. Kaavya, N. Senthil Kumar, G. Laldinmawii, G. Narayanasamy, et al. 2020. "Follow-up Studies in COVID-19 Recovered Patients-Is It Mandatory?" Science of the Total Environment 729:139021. https://doi.org/10.1016/j.scitotenv.2020.139021

Brugliera, L., A. Spina, P. Castellazzi, P. Cimino, P. Arcuri, A. Negro, E. Houdayer, et al. 2020. "Nutritional Management of COVID-19 Patients in a Rehabilitation Unit." European Journal of Clinical Nutrition, 74 (6): 860-863. https://doi.org/10.1038/s41430-020-0664-X

Centers for Disease Control. 2020. What You Should Know about COVID-19 to Protect Yourself and Others. Retrieved from https://www.cdc.gov/coronavirus/2019-ncov/ downloads/2019-ncov-factsheet.pdf (archived).

Centers for Disease Control. Feb. 22, 2021. "Symptoms of Coronavirus." https://www.cdc.gov/coronavirus/2019-ncov/ symptoms-testing/symptoms.html

Chan, K. S., M. Mourtzakis, L. A. Friedman, V. D. Dinglas, C. L. Hough, E. W. Ely, P. E. Morris, R. O. Hopkins, and D. M. Needham. 2018. "Evaluating Muscle Mass in Survivors of Acute Respiratory Distress Syndrome: A 1-Year Multicenter Longitudinal Study. Critical Care Medicine 46 (8): 1238-1246. https://doi.org/10.1097/ CCM.0000000000003183

Cohen, S., J. A. Nathan, and A. L. Goldberg. 2014. "Muscle Wasting in Disease: Molecular Mechanisms and Promising Therapies." Nature Reviews Drug Discovery 14:58-74. https://doi.org/10.1038/nrd4467

Committee on World Food Security. 2021. "Impacts of COVID-19 on Food Security and Nutrition: Developing Effective Policy Responses to Address the Hunger and Malnutrition Pandemic." HLPE Issues Paper. https://www. fao.org/3/cb6720en/cb6720en.pdf

Fernández-Quintela, A., I. Milton-Laskibar, J. Trepiana, S. Gómez-Zorita, N. Kajarabille, A. Léniz, M. González, and M. P. Portillo. 2020. "Key Aspects in Nutritional Management of COVID-19 Patients." Journal of Clinical Medicine 9 (8): 2589. https://doi.org/10.3390/jcm9082589
Iddir, M., A. Brito, G. Dingeo, S. S. F. Del Campo, H. Samouda, M. R. La Frano, and T. Bohn. 2020. "Strengthening the Immune System and Reducing Inflammation and Oxidative Stress through Diet and Nutrition: Considerations during the COVID-19 Crisis." Nutrients 12 (6): 1562. https://doi.org/10.3390/nu12061562

Institute of Medicine. 2005. Dietary Reference Intakes for Water, Potassium, Sodium, Chloride, and Sulfate. Washington, DC: National Academies Press. https://doi. org/10.17226/10925

Lacey, J., J. Corbett, L. Forni, L. Hooper, F. Hughes, G. Minto, C. Moss, et al. 2019. "A Multidisciplinary Consensus on Dehydration: Definitions, Diagnostic Methods and Clinical Implications." Annals of Medicine 51 (3-4): 232-251. https://doi.org/10.1080/07853890.2019.1628352

Stachowska, E., M. Folwarski, D. Jamioł-Milc, D. Maciejewska, and K. Skonieczna-Żydecka. 2020. "Nutritional Support in Coronavirus 2019 Disease." Medicina (Lithuania) 56 (6): 289. https://doi.org/10.3390/medicina56060289

Stokes, E. K., L. D. Zambrano, K. N. Anderson, E. P. Marder, K. M. Raz, S. El Burai Felix, Y. Tie, and K. E. Fullerton. 2020. "Coronavirus Disease 2019 Case Surveillance - United States, January 22-May 30, 2020.” MMWR Morbidity and Mortality Weekly Report 69 (24): 759-765. https://doi.org/10.15585/mmwr.mm6924e2

United States Department of Agriculture. 2020a. "FNS Launches the Online Purchasing Pilot." https://www.fns. usda.gov/snap/online-purchasing-pilot

United States Department of Agriculture. 2020b. Supplemental Nutrition Assistance Program (SNAP)_Adjusting Interview Requirements Due to Novel Coronavirus (COVID-19)_Blanket Approval. Washington, DC.

United States Department of Agriculture. 2021. "WIC-Food Package Substitution Waiver.” https://www.fns.usda.gov/ wic/food-package-substitution-waiver 
Table 1. Protein types and amounts within foods.

\begin{tabular}{|l|l|l|}
\hline Sources & Serving size & \multicolumn{1}{|c|}{ Grams of protein } \\
\hline Meat, poultry, and fish & $3 \mathrm{oz}$. & $21 \mathrm{~g}$ \\
\hline Eggs & $1 \mathrm{egg}$ & $7 \mathrm{~g}$ \\
\hline Dairy Products & $8 \mathrm{oz}$. milk & $8 \mathrm{~g}$ \\
& 6 oz. yogurt \\
& $1-2$ oz. cheese & $8 \mathrm{~g}$ \\
\hline Soy Products & 8 oz. soymilk & $1 / 2$ c. edamame \\
& 1 tbsp. nut butter & $7 \mathrm{~g}$ \\
\hline Nuts and Nut Butters & $1 / 2$ c. mixed nuts & $3-4 \mathrm{~g}$ \\
\hline Legumes and Grains & $1 / 2$ c. quinoa \\
\end{tabular}

